\title{
DEVELOPMENT OF KARST LANDSCAPE UNIT MAPS FOR HOUSTON COUNTY MINNESOTA, U.S.A.
}

\author{
Jeffrey A Green \\ Minnesota Department of Natural Resources \\ Division of Ecological \& Water Resources \\ 3555 9th St. NW Suite 350 \\ Rochester, MN, U.S.A., 55901 \\ jeff.green@state.mn.us \\ John D. Barry \\ Minnesota Department of Natural Resources \\ Division of Ecological \& Water Resources \\ 500 Lafayette Road \\ St. Paul, MN 55155-4040 \\ john.barry@state.mn.us
}

\begin{abstract}
In karst areas, there is a close relationship between the landscape surface and the bedrock below. Classification of the karst landscape helps identify the groundwater characteristics beneath it. Common indicators of karst, such as springs, sinkholes, and sinking streams, are not always present, therefore karst landscapes were identified through analysis of landscape position and geologic setting.
\end{abstract}

A karst landscape unit describes a unique system that includes the surface and its connections to underlying aquifers. Identifying and mapping these units allows for better water and land resource management and planning.

The process began with observations of patterns on the landscape through field observations and Geographic Information System (GIS) reconnaissance. The delineated units were based on geology (bedrock unit); hydrogeology (aquifer characteristics); karst feature type, distribution, and occurrence; spring monitoring; geochemistry; and karst hydrologic characteristics as determined by fluorescent dye tracing including springshed mapping. These elements were combined in a GIS environment, and the unit boundaries were iteratively refined using GIS tools and analysis, Light Detection and Ranging (LiDAR) image review, and field mapping.

Karst landscape unit maps were created as part of the products for Houston County for the Minnesota Depart- ment of Natural Resources (DNR) County Groundwater Atlas (CGA) program. The process developed can be used to develop karst landscape maps for other counties throughout southeastern Minnesota.

The maps were developed to help citizens and government entities identify karst areas so they can deal with the unique myriad of issues that come with karst. The connections to enlarged underground pathways allow for rapid transport of water, creating unpredictable groundwater travel times and flow directions. This makes groundwater in karst settings vulnerable to human activities and complicates remediation efforts for issues like spills or surface applications of chemicals.

\section{Introduction}

In karst, there is a close relationship between the landscape surface and the underlying bedrock. Surface connections to underlying fractures and enlarged pathways allows for rapid transport of water, creating unpredictable groundwater travel times and flow directions. This makes groundwater in karst settings vulnerable to surface activities and complicates remediation efforts for issues like spills or surface applications of chemicals.

Classification of the karst landscape assists in identifying the groundwater characteristics beneath it. Classic signs of karst are not always present at the surface (springs, sinkholes, and sinking streams), therefore the landscapes 
were identified through analysis of karst feature position, and type, elevation, and geologic setting to characterize regions where karst features aren't present.

Maps were developed for Houston County, Minnesota, which is located in southeastern Minnesota in an area underlain by thick sedimentary bedrock (Figure 1). The first encountered bedrock units are predominantly limestone, dolostone, sandstone, siltstone, and shale carbonates and siliciclastics. Karst is predominately present in the carbonates, with pseudokarst occurring in finegrained siliciclastics.

\section{Mapping Methods}

The development of the Karst Landscape Units was an iterative approach that that allowed for refinement of unit boundaries based on data elements and field verification. This ultimately led to GIS methods and the development of interpretation criteria that allows for this method to be replicated in other karst areas.

Karst feature location and type were retrieved from the Karst Features Database, which is a collection of karst related field mapping compiled over decades from researchers, local residents, government agencies, aerial photography, and LiDAR data imagery (Tipping et al., 2015).

Spring locations came from the Minnesota Springs Inventory (Minnesota Department of Natural Resources, 2019a). Time, property access, and staff limitations prohibited field verification of all karst features and springs in the county.

Patterns on the landscape were identified through field observations and reconnaissance and in depth GIS analysis, leading to a preliminary conceptual model of Karst Landscape Units. The model is based on geology (bedrock unit); land surface morphology, karst feature type, distribution, and occurrence; spring monitoring in like settings; karst hydrologic characteristics as determined by fluorescent dye tracing including springshed mapping, hydrogeology (aquifer characteristics), and geochemistry.

Slope class from the Soil Survey Geographic Database (SSURGO) (Natural Resources Conservation Service) and karst features were overlain on the bedrock geology projected onto a one-meter LiDAR hillshade (LiDAR)

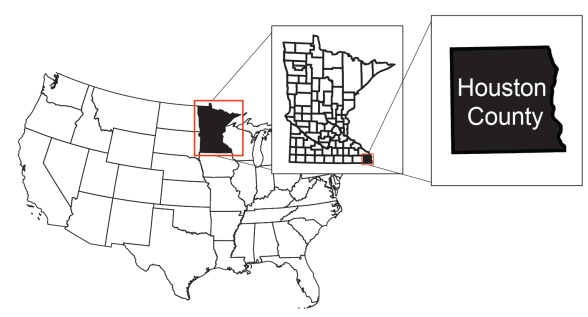

Figure 1. Location map for Houston County, Minnesota

base. These elements were coupled with a hydrogeologic model of flow determined through dye tracing (Minnesota Department of Natural Resources 2019a) aquifer characterization (Runkel et al., 2003), spring flow monitoring, and spring temperature monitoring (Luhman et al., 2011).

Fluorescent dye tracing from pseudokarst stream sinks to springs found they occupy a consistent position in the stratigraphy and have unique hydrologic characteristics. Spring monitoring for discharge, temperature and chemistry were used to categorize springs and demonstrated that the St. Lawrence Formation and Lone Rock Formation springs have distinct flow and chemical characteristics (Green et al., 2014). All of these elements were combined in a GIS environment with geochemistry results of aquifers in the CGA program database. The resultant units were then compared to the landscape during field verification.

\section{Hydrostratigraphy}

Houston County is underlain by sedimentary bedrock of the Hollandale embayment (Steenberg, 2014). The region was not glaciated during the last two major glacial epochs and is informally known as the Driftless Area. The first encountered bedrock units are Ordovician and Cambrian in age and are predominantly limestone, dolostone, sandstone, siltstone, and shale (Steenberg, 2014). Karst features are predominately present in the Ordovician carbonates which are prevalent in the upland areas; pseudokarst occurs in fine-grained siliciclastics in incised valley settings. Where saturated, the carbonates and siliciclastics units are aquifers. The aquifers transmit water through conduits, fracture networks, and/or porous media. Aquitards typically have low vertical permeability but may have high horizontal permeability. Aquitards 
are primarily composed of very fine-grained sand, silt, shale, or dense carbonate, across which vertical fractures are poorly connected (Figure 2).

In shallow carbonate aquifers turbulent flow dominates and groundwater flows rapidly through subsurface voids, conduits, and fractures. Human activities impact the uppermost carbonate aquifers of the region. Nitrate, pathogens, and other contaminates move into the shallow groundwater system by open conduits or diffuse flow through the thin surficial cover (Libra et al., 1984; Runkel et al., 2013).

Surface karst in Houston County is primarily found in areas where there is less than fifteen meters of unconsolidated material above these carbonate units: the Cummingsville, Platteville, and Shakopee formations; and Oneota Dolomite. The St. Peter Sandstone, a siliciclastic unit, is included because of the numerous sinkholes and fractures that have been identified in the unit across southeastern Minnesota.

\section{Karst Features}

The formation of surface karst features (sinkholes, stream sinks, and springs) is primarily controlled by the underlying bedrock units and structure and depth to the bedrock surface and known high transmissivity zones.

Nearly 300 sinkholes have been mapped in the county, ranging in size from a $1 \mathrm{~m}$ in diameter to 0.4 ha, with depths from 0.3-6 m. Most form as cover-collapse sinkholes where the soil underneath is carried away into conduits and channels in the bedrock. The highest density of sinkholes occurs in areas where the Shakopee Formation is the first bedrock aquifer. High sinkhole density occurs where two major conduit systems are near the land surface: 1) the St. Peter-Shakopee contact and 2) the Shakopee-Oneota contact (Dalgleish and Alexander, 1984; Tipping et al., 2001). Each of these systems occurs at unconformities where karstification occurred (Alexander et al., 2013). These contact zones were found to be almost exclusively in the Karst Rolling Upland unit.

Springs are points where groundwater emerges from the land surface. Combining springs in the Minnesota Spring Inventory with probable locations from airphoto and LiDAR interpretation suggests over 300 springs occur in the county. The majority of springs emanate from the St. Lawrence and Lone Rock Formations and pro-

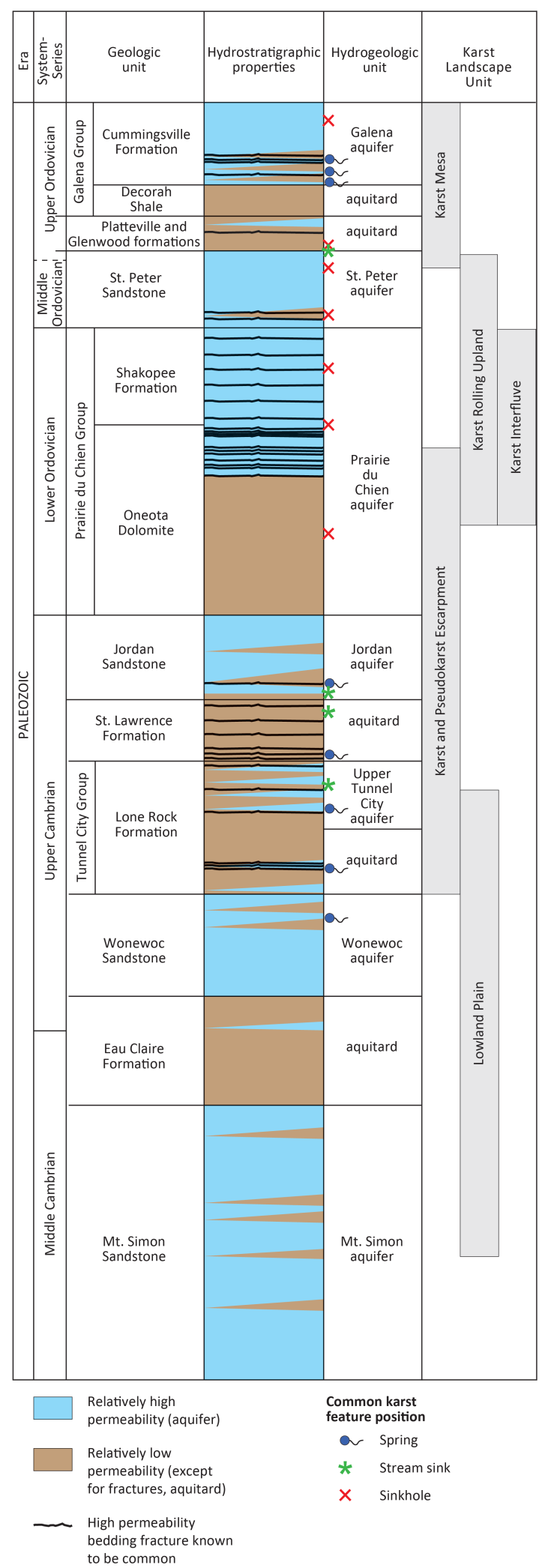

Figure 2. Bedrock Geology, Hydrostratigraphy, common karst feature position, and Karst Landscape Unit position for Houston County. Modified from Steenberg, 2014. 
vide cool isothermal water that supplies the numerous trout streams of the county.

Stream sinks are points where surface water disappears into the subsurface. The locations of stream sinks may shift over time and a range of surface water flow conditions. Stream sinks occur in two forms: discrete locations or locations where water disappears gradually in a stream reach. Where the first bedrock is the St. Peter Sandstone or Shakopee Formation, the discrete form is most common. Both forms are common where the first bedrock is the lowermost Jordan, St. Lawrence or Lone Rock formation.

Pseudokarst is defined as "karst-like morphology primarily produced by a process other than dissolution" (Halliday, 2007). In Houston County, pseudokarst is commonly found in valleys where the St. Lawrence or Lone Rock formation is the first bedrock. Groundwater time of travel detected by dye tracing pseudokarst stream sinks is similar to karst, however these conduits do not appear to be the product of carbonate dissolution (Green et al., 2012; Barry et al., 2015, 2018).

Springsheds are defined as "those areas within groundand surface-water basins that contribute to the discharge of a spring" (Florida Geological Survey, 2003). Surfacewater basins that contribute surface runoff to stream sinks were delineated by determining their upstream catchment areas using watershed tools and digital elevation models (DEM). In the vicinity of deeply incised valleys, many large surface water catchments are directly contributing to groundwater via sinking streams and losing stream reaches.

\section{Karst Landscape Units}

The positions of the Karst Landscape Units are schematically shown next to the stratigraphy in Figure 2 and are summarized in the detailed descriptions below. The stratigraphy list below summarizes relative permeability and whether the formation is considered an aquifer or aquitard. Most of the hydrostratigraphic information comes from Runkel et al. (2003).

Karst mesa

- Cummingsville Formation: aquifer with very high fracture permeability, relatively low matrix permeability

- Decorah Shale: aquitard with very low permeability
- Platteville and Glenwood formations: aquitard with generally low permeability, high permeability fractures

Karst upland

- St. Peter Sandstone: aquifer with moderate intergranular permeability with high permeability fractures

Karst upland and karst interfluve

- Shakopee Formation: aquifer with high fracture permeability, relatively low matrix permeability

- Oneota Dolomite: aquifer with generally low permeability

Karst and pseudokarst escarpment

- Jordon Sandstone: aquifer with relatively high intergranular permeability with high permeability fractures

- St. Lawrence Formation: aquitard with generally low permeability

- Lone Rock Formation: aquitard with generally low permeability

Karst and pseudokarst escarpment, lowland plain

- Lone Rock Formation: aquitard with generally low vertical permeability; unit has high horizontal permeability

- Wonewoc Sandstone: aquifer with moderate intergranular permeability

Lowland plain

- Eau Claire Formation: aquitard with primarily low permeability

- Mt. Simon: aquifer with relatively high intergranular permeability

\section{Karst Mesa}

The Karst Mesa Unit has the youngest (upper Ordovician) bedrock in the county. It is prominent in Figure 3 as ridges in the southwestern part of the county where the Karst Mesa rises above the surrounding upland plateau. Unconsolidated material over bedrock is generally less than 15 meters thick. The top of the mesas are underlain by the Cummingsville limestone, the side slopes are underlain and interbedded with Decorah shale, Platteville limestone and Glenwood shale Formations, and St. Peter Sandstone (Steenberg 2014). Sinkholes are isolated in the Cummingsville and Platteville, typically with diameters less than 9 meters wide. The unit has 2 percent of the mapped sinkholes. Springs and seepage occur at the 


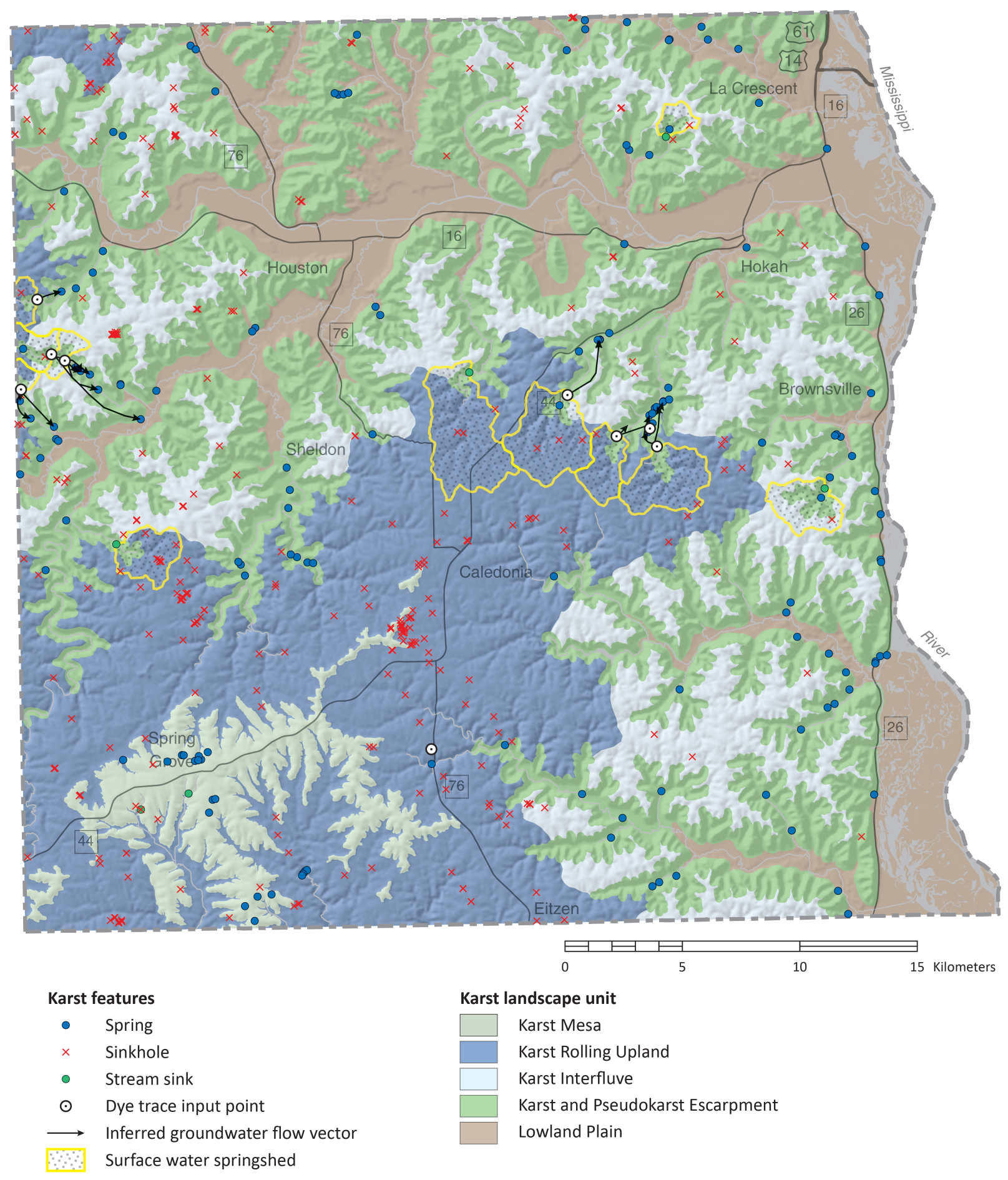

Figure 3. Karst landscape units of Houston County, Minnesota. Surface water springsheds show the contributing areas of the landscape that drain to sinking stream locations.

contact between the Cummingsville and the Decorah. The top of the mesa has slopes less than 9 percent with the backslope dropping off steeply at $10-30$ percent. The footslope is formed by the St. Peter sandstone formation. Using slope data from SSURGO, the final boundary between the Karst Mesa Unit and the Karst Rolling Upland 
unit has a slope class of less than 8 percent. The primary factors describing it are bedrock geology, landform morphology, spring occurrence and sinkhole density.

\section{Karst Rolling Upland}

The Karst Rolling Upland Unit surrounds the karst mesa unit and forms a plateau that covers the central, western and northwestern areas of the county (Figure 3). It is a dissected plain of rolling topography that is moderate to steeply sloping. Unconsolidated materials are generally less than 15 meters thick and overlie the St. Peter sandstone or the carbonate bedrock of the Prairie du Chien Group. Sinkholes are the primary surface karst features and the unit has 69 percent of the mapped sinkholes. They occur both individually and in clusters, primarily ranging in width from 1-75 $\mathrm{m}$ and in depth from 0.3-9 $\mathrm{m}$. Many are developed above a regionally recognized high transmissivity layer located at the contact of the Shakopee-Oneota. Subsidence frequently occurs near this zone, including catastrophic wastewater treatment facility failures in southeast Minnesota (Alexander et al., 2013). Another mappable characteristic of the Karst Rolling Upland is wells completed in the Shakopee, Oneota and Jordan sandstone (County Well Index), indicating saturated conditions (Figure 4). Saturation in these units was also verified via the locations of springs that emanate from these formations. Although not abundant, they occur in dissected valleys down slope at the base of the Karst Rolling Upland unit and the Karst and Pseudokarst Escarpment. Some areas of the unit are delineated as surface-water springsheds that contribute flow to St. Lawrence or Lone Rock stream sinks.

\section{Karst Interfluve}

The Karst Interfluve is typified by rolling topography on narrow ridges that extend from the Karst Rolling Upland and divide stream valleys. These ridges are prominent local topographic features that commonly have unique geographic names such as Dog Square Ridge, Union Ridge, and Irish Ridge. There is generally less than 15 meters of unconsolidated material overlying the Shakopee limestone and Oneota dolostone. The unit has 23 percent of the mapped sinkholes which primarily occur individually and are generally 0.6-30 m wide and 0.3-6 $\mathrm{m}$ deep. However, a few interfluves have dense clusters of small sinkholes that are typically less than $9 \mathrm{~m}$ in diameter.
The primary characteristic that separates this unit from the Karst Rolling Upland is the dewatered nature of the underlying Prairie du Chien and Jordan bedrock. This lack of saturation is evident in the absence of wells finished in those units and was also verified by the dearth of springs discharging from these units in the valleys adjacent to the karst interfluves (Figure 4).

\section{Karst and Pseudokarst Escarpment}

The Karst and Pseudokarst Escarpment is typified by dissected bluffs with steep slopes that provide the transition from the karst rolling upland and karst interfluve to the lowland plain. The ridgetops and hill shoulders are underlain by Oneota dolostone. The upper side slopes are underlain by Jordan Sandstone, the lower side slopes and footslopes by St. Lawrence Formation (siliciclastic), and the toe slopes are underlain by Lone Rock Formation (siliciclastic). Each of these formations are commonly found as the first bedrock in deeply incised valleys.

Sinkholes and solution openings are found in the ridgetops and hill shoulders underlain by Oneota dolostone (Figures 3 and 4). This unit has 8 percent of the mapped sinkholes. Streams commonly sink into voids in the lowermost Jordan and the upper St. Lawrence on tributary streams in valleys. The stream sink locations are ephemeral, as they often move up and down the valley depending on stream stage. Flood events can close or reopen stream sinks and change streams' flow regime. One example is Indian Springs Creek, which is now perennial, but in 1920 it was found to be disappearing into the streambed (Surber, 1920). There are also streams that lose flow but do not totally disappear as they cross the St. Lawrence. Several stream sinks have been mapped where the Lone Rock is first bedrock.

Surface-water springsheds, where surface flow becomes groundwater, terminate at stream sinks in the fine siliciclastic lowermost Jordan, upper St. Lawrence and upper Lone Rock Formations. These formations lack the evidence of bedrock dissolution, large conduit networks, subsurface voids, and sinkholes that would classify them as karst and are therefore classified as pseudokarst. Dye tracing investigations (Green et al., 2008, 2012, 2015; Barry et al., 2015, 2018) have shown that groundwater time of travel from stream sinks in this setting to the spring resurgence points approaches that of classic karst aquifers. Groundwater time of travel in these units 


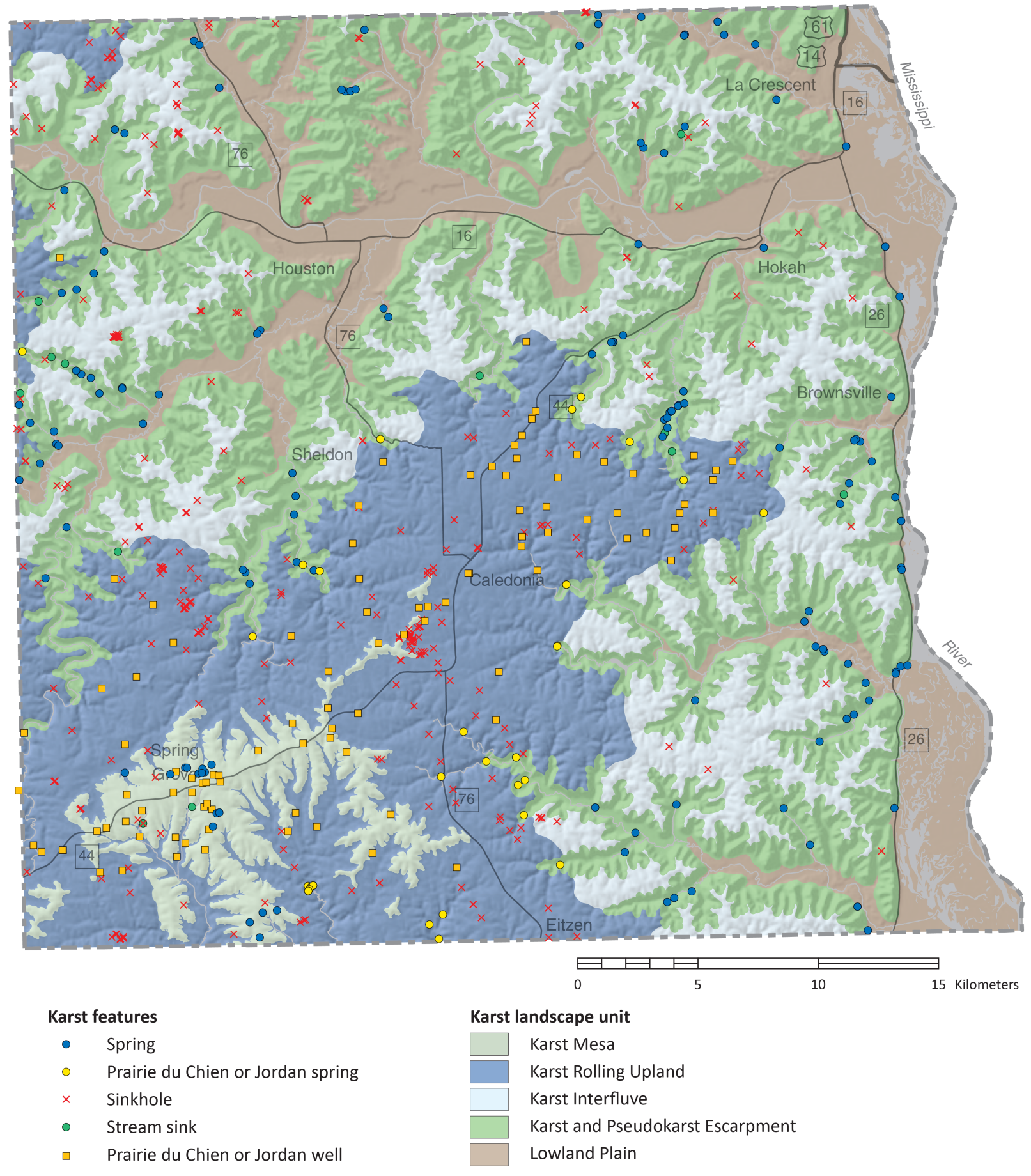

Figure 4. Karst landscape units of Houston County, Minnesota and the distribution of Prairie du Chien and Jordan aquifer wells and springs.

ranges from dozens to hundreds of meters per day. The stream sinks function as points for recent water to infiltrate into the regional groundwater flow system.
Springs are numerous, primarily discharging from the St. Lawrence and the Lone Rock formations, although there are several large Jordan springs in the county. Field 
investigations at several St. Lawrence and Lone Rock springs in southeast Minnesota has shown that they primarily respond quickly to precipitation and runoff events. However, unlike karst conduit springs, they do not have corresponding changes in temperature, chemistry, or turbidity.

Water sampling of select wells and springs in the county was carried out by the Minnesota DNR as part of its County Geologic Atlas Program (Barry in progress). This work and previous investigations (Runkel et al., 2018, Barry et al., 2015, 2018) have demonstrated that the St. Lawrence Formation and the Lone Rock Formation springs reflect mixing of recent water with older waters and is one of the identifying characteristics of this landscape unit.

To standardize the delineation of this unit, various buffer distances were set from the St. Lawrence Formation and the Jordan Formation. The resulting polygons needed to include all of the Jordan and St. Lawrence subcrops, the Lone Rock footslopes and the Oneota ridge shoulders. The area includes springs and stream sinks and fits with our conceptual model of the groundwater mixing zone at the edges of the dissected valleys. We accomplished this by setting a 150-meter buffer from the Jordan Formation polygons in ArcMap. This delineation fit with our observations and data on spring chemistry, spring discharge, spring stratigraphy, stream sink locations and groundwater hydrology.

\section{Lowland Plain}

The Lowland Plain is the only non-karst landscape in the county (Figures 3 and 4). It is found on the floors of the dissected valleys across the county. The largest areas of the unit are in the Mississippi River and Root River valleys. The Lowland Plain generally has slopes generally less than 6 percent, although steep areas along major streams and at its boundaries with the Karst and Pseudokarst Escarpment are exceptions.

Unconsolidated material ranges from less than $15 \mathrm{~m}$ to over $60 \mathrm{~m}$, primarily filling buried bedrock valleys. Lowland Plain unconsolidated deposits are underlain by bedrock of the lower Lone Rock Formation, Wonewoc Sandstone, Eau Claire Formation (siltstone and shale), and Mt. Simon Sandstone.
Flowing wells commonly occur in wells completed in the Eau Claire and Mt. Simon formations, as they are under artesian conditions in the river valleys and along the banks of the Mississippi River. Springs are less common in this landscape unit; where present they typically emanate from the lowermost Lone Rock, upper Wonewoc, or from unconsolidated sands.

This unit was delineated by selecting the areas with Wonewoc, Eau Claire or Mt. Simon Sandstone as first bedrock. The Lone Rock Formation polygons were then clipped to add to the Lowland Plain those areas with less than 6 percent slope.

\section{Summary}

Karst feature inventory and mapping is a standard practice for the analysis and management of karst areas. In Houston County, Minnesota, karst landscape units were developed using additional factors. This process characterized the karst and pseudokarst areas of the county and assisted in the development of interpretation criteria. Following refinement of the processes, the methodology was applied to neighboring Winona County, Minnesota with successful results.

These maps will be used by citizens, local and state officials, and businesses to provide guidance to a myriad of water resource and land management issues.

\section{Acknowledgments}

Holly Johnson assisted greatly with cartography, graphics development, and editing.

\section{References}

Alexander, EC Jr, Runkel AC, Green JA. 2013. Deep time origins of sinkhole collapse failures in sewage lagoons in southeast Minnesota In: Land L, Doctor DH, Stephenson JB editors, 2013. Sinkholes and the Engineering and Environmental Impacts of Karst: Proceedings of the Thirteenth Multidisciplinary Conference, May 6-10, Carlsbad, New Mexico: NCKRI Symposium 2. Carlsbad (NM); National Cave and Karst Research Institute 
Barry JD, Green JA, Steenberg JR. 2015. Conduit flow in the Cambrian Lone Rock Formation, Southeast Minnesota, U.S.A. In: Doctor DH, Land L, Stephenson JB, editors. Sinkholes and the Engineering and Environmental Impacts of Karst: Proceedings of the Fourteenth Multidisciplinary Conference, October 5-9 2015. University of South Florida, Digital Collections, Rochester, MN, pp 31-42.

Barry JD, Green JA, Rutelonis, JW, Steenberg JR, Alexander EC Jr. 2018. Coupling Dye Tracing, Water Chemistry, and Passive Geophysics to Characterize a Siliciclastic Pseudokarst Aquifer, Southeast Minnesota, U.S.A. In: Sasowsky, ID, Byle, MJ, Land L, editors. Sinkholes and the Engineering and Environmental Impacts of Karst: Proceedings of the Fifteenth Multidisciplinary Conference; 2018 April 2-6; University of South Florida, Digital Collections, Rochester, MN, pp 5-16.

Barry JD, 2020. Minnesota Department of Natural Resources, County Geologic Atlas Part B, Groundwater Atlas of Houston County, MN (in progress).

County Well Index. Database created and maintained by the Minnesota Geological Survey, University of Minnesota, with the assistance of the Minnesota Department of Health. http://www. health.state. mn.us/divs/eh/cwi/. Accessed May 2019.

Dalgleish J, Alexander EC Jr. 1984. Sinkhole distribution in Winona County, Minnesota. In: Beck, B. editor, Sinkholes: Their Geology, Engineering and Environmental Impact, A.A. Balkema, Rotterdam, The Netherlands, pp. 79-85.

Florida Geological Survey. 2003. Florida spring classification system and spring glossary: Special Publication no. 52, 17 p.

Green JA, Luhmann AJ, Peters AJ, Runkel AC, Alexander, EC, Jr, Alexander SA. 2008. Dye tracing within the St Lawrence confining unit in southeastern Minnesota. In: Yuhr L, Alexander EC, Jr, Beck B, editors. Sinkholes and the Engineering and Environmental Impacts of Karst, American Society of Civil Engineers, Proceedings GSP 183, p 477-484.
Green JA, Runkel AC, Alexander EC Jr. 2012. Karst conduit flow in the Cambrian St. Lawrence formation, southeast Minnesota. USA Carbonates Evaporites 27(2):167-172

Green JA, Barry JD, Alexander EC Jr. 2014. Springshed Assessment Methods for Paleozoic Bedrock Springs of Southeastern Minnesota. Report to the Legislative-Citizen Commission on Minnesota Resources. Minn. Dept. Natural Resources, St. Paul, MN, 48 p.

Green JA, Alexander, EC Jr. 2015. Creation of a Map of Paleozoic Bedrock Springsheds in Southeast Minnesota. In: Doctor D, Land L, Stephenson, JB editors. Sinkholes and the Engineering and Environmental Aspects of Karst. Proceedings of the Fourteenth Multidisciplinary Conference; 2015 Oct. 5-9; Rochester, MN. National Cave and Karst Research Institute Symposium 5. Carlsbad, NM. p 211-222.

Halliday WR. 2007. Pseudokarst in the 21st century. Journal of Cave and Karst Studies, v. 69, no. 1, p. 103-113.

Karst Features Database (Karst Feature Inventory Points), University of Minnesota, Department of Geology and Geophysics; Minnesota Department of Natural Resources, available from the Minnesota Geospatial Commons website. Accessed July 2019.

LiDAR Elevation Data for Minnesota, Minnesota LiDAR based DEM, Minnesota Department of Natural Resources, available from the Minnesota Geospatial Commons website.

Libra RD, Hallberg GR., Ressmeyer GG, Hoyer, BE. 1984. Groundwater quality and hydrogeology of Devonian carbonate aquifers in Floyd and Mitchell counties, Iowa: Iowa Geological Survey Open-File Report 84-2, Pt. 1.

Luhmann AJ, Covington MD, Peters AJ, Alexander SC, Anger CT, Green JA, Runkel AC, Alexander EC, Jr, 2011, Classification of thermal patterns at karst springs and cave streams: Groundwater 49 (3): 324-335.

Minnesota Department of Natural Resources a, Minnesota Groundwater Tracing Database, https:// 